\title{
Training in Flap Harvesting using Corrosion Casted Pig Latissimus Dorsi Muscle Flaps Choosing the Optimal Plastic Compound for Corrosion Casting
}

\author{
ALEXANDRU NISTOR ${ }^{1 *}$, AGNETA MARIA PUSZTAI ${ }^{2 \# *}$, MIRCEA CONSTANTIN SORA ${ }^{3}$, BOGDAN HOINOIU $^{1}$, MIHAI IONAC ${ }^{1}$, \\ PETRU MATUSZ² \\ ${ }^{1}$ Victor Babes University of Medicine and Pharmacy Timisoara, Department of Microsurgery, 2 Eftimie Murgu Sq.,300041, \\ Timisoara, Romania \\ ${ }^{2}$ Victor Babes University of Medicine and Pharmacy Timisoara, Department of Anatomy, 2 Eftimie Murgu Sq., 300041, Timisoara, \\ Romania \\ ${ }^{3}$ Morfology Centre, Medical Faculty, Sigmund Freud Privatuniversitat, Campus Prater Freudplatz 1, A-1020 Wien A-1090 Wien, \\ Austria
}

\begin{abstract}
Plastic compounds have been used for several decades to generate anatomical constructs for the training of new surgeons and medical students alike. The present study seeks to highlight the advantages and disadvantages of two different plastic compounds (Technovit 7143 and Epoxi BIODUR ${ }^{\circledR} E 12$ ) used to create corrosion casts of the vascular branching patterns in free muscle flaps. Porcine latissimus dorsi muscle free flaps were used in this study to create corrosion casts of their vascular branching tree by injecting the two different plastic compound into the main arterial supply. The casts generated by Epoxy BIODUR ${ }^{\circledR}$ E12 have superior qualities compared to the casts injected with Technovit 7143, because the injection process is smoother at all branching levels, without dilation, strictures or intramuscular extravasation of the injectable plastic compound. The corrosion casts resulted from injecting Epoxy BIODUR ${ }^{\circledR}$ E12 exhibit better elasticity and better resistance to mechanical handling compared to the ones injected with Technovit 7143.
\end{abstract}

Keywords: latissimus dorsi muscle flap, plastic polymers, corrosion casts, flap harvesting, flap dissection training

Plastic compounds have been used for several decades to generate anatomical constructs for the training of new surgeons and medical students alike. Previous publications show three main directions of study in this area: (i) corrosion casting designed to highlight the vascular-ductal systems of the parenchymal organs [1-4]; (ii) creating plastinated anatomical cross-sections, with computer aided three-dimensional reconstruction and modeling of the anatomical structures [5-9]; (iii) embedding of anatomical preparations in plastic mass [10,11]. In recent decades, the development of microsurgery has allowed the use of free muscle flaps (with or without fasciocutaneous structures) to cover or fill important soft tissue defects. The latissimus dorsi muscle is one of the most used muscle structures in reconstructive microsurgery in human patients [12] and displays a type $V$ pattern of vascular supply, according to Mathes and Nahai [13], with one dominant pedicle and secondary segmental pedicles. The porcine latissimus dorsi muscle displays the same patten of vascular supply as its human counterpart and thus harvesting a porcine vascularized free latissimus dorsi muscle flap simulates accurately the human counterpart, due to the almost identical anatomy of the swine and human muscle $[14,15]$.

Currently, the most used plastics masses for creating anatomical corrosion casts are produced by Technovit (Heraeus Kulzer GmbH, Wehrheim, Germany) and BIODUR $^{\circledR}$ (BIODUR Products GmBH, Germany) [16]. Injection of muscular vascular systems is the latest technique to highlight the vascular pattern [17]. The present research seeks to highlight the advantages and disadvantages of different plastic compounds used in the creation of vascular pattern corrosion casts of the porcine latissimus dorsi muscle.

\section{Experimental part}

Ten healthy pigs (Sus scrofa domesticus) of Landrace/ Large White/Duroc hybrid breed were obtained from Smithfield Ferme (Timisoara, Romania), both male and female ( 3 male, 7 female), weighing $28-36 \mathrm{~kg}$. The experimental animals were used prior to flap harvesting for surgical training, carried out under general inhalatory anesthesia and were treated according to the Policy for the Use of Animals in Teaching and Training recommended by the Federation of European Laboratory Animal Science Associations (FELASA). The experiments were approved by the Ethics Committee of the Victor Babes University of Medicine and Pharmacy, Timisoara. After completion of the surgical training, the experimental animals were euthanized using intravenous injection of $0.3 \mathrm{ml} / \mathrm{kg}$ embutamide (T-61 ${ }^{\odot}$, Merck Animal Health, Germany).

Twenty latissimus dorsi muscle free flaps were harvested at necropsy, with the axial arterial supply traced proximally to the level of the subscapular artery and used to study the intramuscular diffusion proprieties of the plastic compounds. 10 harvested free muscle flaps, originating both left and right, were injected with Technovit 7143 plastic compound (Heraeus Kulzer $\mathrm{GmbH}$, Wehrheim, Germany) and the other 10 free flaps with BIODUR ${ }^{\circledR} E 12$ (BIODUR Products $\mathrm{GmBH}$, Germany), seeking to compare the advantages and disadvantages of using these two plastic compounds in creating corrosion casts of the intramuscular vascular branching pattern in the procine latissimus dorsi free muscle flaps. 
The Technovit 7143 injectable plastic compound, based on methacrylate copolymers, was prepared for injection by combining a partially polymerized monomer base (Technovit 7143, Heraeus Kulzer GmbH, Wehrheim, Germany) with a catalyst of Methyl methacrylate and N,Ndimethyl-p-toluidine (TechnovitUniversal Liquid, Heraeus Kulzer $\mathrm{GmbH}$, Wehrheim, Germany) in a ratio of 1:1, with a hardening time of 10-15 min. The injected plastic compound was then allowed to polymerize for $24 \mathrm{~h}$ in the harvested anatomical construct.

The Epoxy BIODUR ${ }^{\circledR}$ injectable plastic compound (BIODUR Rathausstr.18, 69126 Heidelberg, Germany) was prepared by mixing: BIODUR ${ }^{\circledR}$ E12 (resin) / BIODUR ${ }^{\circledR}$ E6 (hardener), in ratio of 10:1 with a hardening time of $24 \mathrm{~h}$.

For each injectable plastic compound, a $50 \mathrm{ml}$ syringe (Beckton Dickinson Luer-Lok ${ }^{\text {TM }}$, New Jersey, USA) was used to inject the mixtures under hand pressure until the entire intramuscular arterial system was filled and the plastic compound could be seen to extrude from the edge of the anatomic specimen. Corrosion casting was performed in order to remove the muscular and fascial structures by submerging the anatomical specimens in sodium hydroxide solution $40 \%$ (w/w \%) for 3 days. Corrosion with sodium hydroxide was interrupted by daily washing under running tap water to encourage the disposal of the organic tissues. The obtained vascular corrosion casts were rinsed $24 \mathrm{~h}$ in running tap water and finally photographed and analyzed.

\section{Results and discussions}

The porcine latissimus dorsi muscle is supplied in its dorso-caudal part by dorsal intercostal arteries (secondary segmental pedicles), while the remaining bulk of the muscle is supplied thorough the dominant pedicle - the thoraco-dorsal artery, a branch of the subscapular artery for the ventro-cranial part of the muscle [18].

\footnotetext{
Table 1
}

LOCATION OF FRACTURES IN THE CORROSION CASTS BASED ON THE BRANCHING LEVEL AND ON THE PLASTIC COMPOUND USED

\begin{tabular}{|l|l|l|l|l|l|}
\hline Branching level & \multicolumn{1}{|c|}{ Arterial level } & \multicolumn{3}{|c|}{ Level of corrosion casts damage } \\
\cline { 3 - 6 } & & & \multicolumn{2}{|l|}{ Technovit 7143 poxy BIODUR 12} \\
\cline { 3 - 6 } & & $\begin{array}{l}\text { Damaged } \\
\text { corrosion } \\
\text { casts }\end{array}$ & $\begin{array}{l}\text { Total } \\
\text { damage }\end{array}$ & $\begin{array}{l}\text { Damaged } \\
\text { corrosion } \\
\text { casts }\end{array}$ & $\begin{array}{l}\text { Total } \\
\text { damage }\end{array}$ \\
\hline Order I & Thoracodorsal artery & $4 / 10 \mathrm{pcs}$ & $40 \%$ & $0 / 10 \mathrm{pcs}$ & $0 \%$ \\
\hline Order II & $\begin{array}{l}\text { Dorso-cranial branch and } \\
\text { ventro-caudal branch }\end{array}$ & $3 / 10 \mathrm{pcs}$ & $30 \%$ & $0 / 10 \mathrm{pcs}$ & $0 \%$ \\
\hline Order III & $\begin{array}{l}\text { Third order dichotomic } \\
\text { intramuscular branches }\end{array}$ & $4 / 10 \mathrm{pcs}$ & $40 \%$ & $2 / 10 \mathrm{pcs}$ & $20 \%$ \\
\hline Order IV & $\begin{array}{l}\text { Four order dichotomic } \\
\text { intramuscular branches }\end{array}$ & $7 / 10 \mathrm{pcs}$ & $70 \%$ & $2 / 10 \mathrm{pcs}$ & $20 \%$ \\
\hline Order V & Marginal branches & $10 / 10 \mathrm{pcs}$ & $100 \%$ & $5 / 10 \mathrm{pcs}$ & $50 \%$ \\
\hline
\end{tabular}

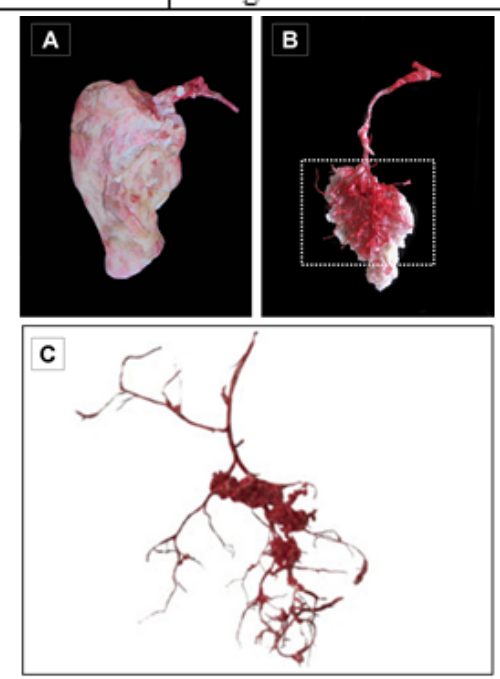

Fig. 1. A. Harvested left latissimus dorsi muscle flap with thoracodorsal pedicle, injected with Tehnovit 7143. B. Partial corrosion cast of the anatomical specimen injected with Tehnovit 7143, having the vascular network partially exposed. C. Detail of the corrosion cast showing the branching system (order

II-V) and the damage to the injected plastic compound after corrosion with sodium hydroxide. Branches of order IV and V show extensive damage [Color figure can be viewed in the online issue, which is available at www.revmaterialeplastice.ro].

The toracodorsal artery continues the path of the subscapular artery and penetrates the muscle on its posterior side, in a cranial to caudal direction in the muscle, muscle bulk the arterial trunk divides (branches of the second order) in a dorsal branch, running parallel to the dorsal edge of the muscle and a ventral, oblique branch, body After parth the of the third order) into a cranial branch (oriented to the (parallel to the dorsal edge of the muscular body). The third order), into dichotomic dorsal and ventral branches. Injections with Technovit 7143 (fig.1) and Epoxy BIODUR ${ }^{\circledR}$ 2 (fig.2) allowed constant evidence of fourth and fifth horacodorsal artery, several branches similar to those The corrosi

The corrosion casts generated from the anatomical ere analyzed separately for each of the two plastics pounds used for injection (Technovit 7143 and Epoxy corrosion casts ruptured amongst the five orders of magnitude; (ii) uniformity of injected vascular diameter thavasation of the injectable plastic compound.

The trunk of the thoracodoral artery showed complete 40\% and of the dorsocervical branch in $30 \%$ of the corrosion casts injected with Technovit 7143. Compared to this, the casts injected with Epoxy BIODUR ${ }^{\circledR}$ 

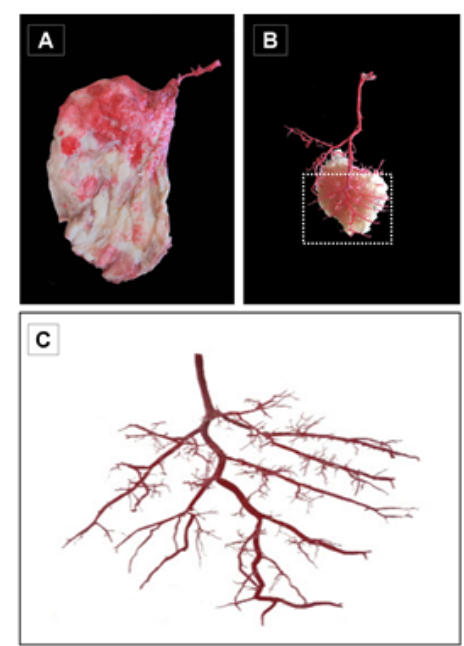

Fig. 2. A.Harvested left latissimus dorsi muscle flap with thoracodorsal pedicle, injected with Expoy BIODUR ${ }^{\circledR}$ E12. B.

Partial corrosion cast of the injected anatomical specimen, with the vascular network partially exposed after injection with Expoy BIODUR ${ }^{\circledR}$ E12. C. Detail of the corrosion cast showing the branching system (order II-V) and the damage to the injected plastic compound after corrosion with sodium hydroxide. Branches of order IV and V show extensive damage

[Color figure can be viewed in the online issue, which is available at www.revmaterialeplastice.ro]

E12 showed no rupture in the first and second order of branches (table 1). Third and fourth dichotomic intramuscular branches showed ruptures in the case of both plastic compounds, but significantly more frequent when using Technovit 7143 (fig. 1). The casts injected with EpoxyBIODUR ${ }^{\circledR}$ E12 (fig. 2) displayed a better preservation of the vascular branching pattern. The more frequent ruptures of order $V$ marginal branches ( $100 \%$ damage for casts injected with Technovit 7143 and 50\% damage for Epoxi BIODUR ${ }^{\circledR}$ E12 injected casts) was correlated with the accentuated adhesion of saponified residues resulting from the sodium hydroxide corrosion process. The rapid polymerization process of Technovit 7143 makes the injected vascular trinisations uneven and low-diameter areas are more commonly associated with ruptures of corrosion casts. The $24 \mathrm{~h}$ period required for Epoxy BIODUR ${ }^{\circledR}$ E12 polymerization leads to a uniformity in the appearance of the injected arterial trunks, without dilation or strictures. The rapidly increasing viscosity of the intravascular injected Technovit 7143 requires an increase of the injection pressure in order to keep the plastic compound advancing, which causes extravasation of the plastic compound in the third and fourth order arterial branches.

Linear and total shrinkage of Epoxy BIODUR ${ }^{\circledR}$ E12 plastic compound is minimal compared to Technovit 7143 [19].

\section{Conclusions}

Porcine muscle free flaps provide an easy teaching and training model for surgeons aiming to better understanding the vascular architecture of free flaps. Injecting anatomical specimens and creating plastic corrosion casts facilitates the educational process and the understanding of intramuscular tridimensional distribution of the arterial pattern. For these purposes, Epoxy BIODUR ${ }^{\circledR}$ E12 has superior qualities compared to Technovit 7143 because the injected plastic compound is uniform at all levels of magnitude without signs of dilation, strictures or intramuscular extravasation. The corrosion casts made with Expoy BIODUR ${ }^{\circledR}$ E12 have a better elasticity and good resistance to mechanical handling compared to the ones obtained by injecting Technovit 7143.
Acknowledgements: This work was supported through a grant financed by the Victor Babes University of Medicine and Pharmacy Timisoara (GrantPII-C1-TC-2013-15250/19.12.2012, Acronym ANGIOPERF).

\section{References}

1. ZAHOI, D.E., DAESCU, E., ENACHE, A., BARSASTEANU, F., PUSZTAI, A.M. Morphological variability of the vascularisation of the polar renal parenchyma. A study on corrosion casts and dissections. The FASEB J., 2011, 25 (1 Supplement), lb7-lb7.

2. IOANOVICIU, S.D., IVAN, C., MATUSZ, P., OLARIU, S., LIGHEZAN, D. Morphological Variability of the Hepatic Portal Vein Medial Branches Study on corrosion casts. Mat. Plast., 52, no. 1, 2015, p. 113.

3. IOANOVICIU, S.D., IVAN, C., MATUSZ, P., OLARIU, S., LIGHEZAN, D. Morphological Variability of the Hepatic Portal Vein Posterior Branch: Study on Corrosion Casts. Mat.Plast., 52, no. 2, 2015, p. 263.

4. SAS, I., BEDREAG, O., HOINOIU, B., MICLAUS, G.D., NISTOR, A., CITU, I., BANCIU, C.D., IOANOVICIU, S.D. Morphological Analysis of Pig Femoro-iliaco-aorto-renal System on Corrosion Casts and MDCT Angiography. Preliminary report for stenting training. Mat.Plast., 52, no. 3,2015, p. 317

5. SORA, M.C., MATUSZ, P. General considerations regarding the thin slice plastination technique. Clin Anat., 23, no. 6, 2010, pp. 734-6.

6. SORA, M.C., MATUSZ, P. Study of the vascular architecture of bones using the plastination technique. Clin Anat., 25, no. 2, 2012, pp. 258-9. 7. SORA, M.C., JILAVU, R., MATUSZ, P. Computer aided threedimensional reconstruction and modeling of the pelvis, by using plastinated cross sections, as a powerful tool for morphological investigations. Surg. Radiol. Anat., 34, no. 8, 2011, pp. $731-736$

8. SORA, M-C., BINDER, M., MATUSZ, P., PLES, H., SAS, I. Slice Plastination and Shrinkage. Mat. Plast., 52, no. 2, 2015, p. 186.

9. SORA, M-C., ERMAN, G., PIRTEA, L., BOIA, M., MATUSZ, P., SAS, I. Three Dimensional Reconstruction and Modeling of Complex Pelvic Anatomical Structures by Using Plastinated Cross Sections. Mat.Plast., 52, no. 3, 2015, p. 381.

10. PLES, H., SINESCU, C., FLOREA, L., TOPALA, F.I., RUSU, L.C., CIRES, D.N., PODOLEANU, A. Plastination Biopsy Samples from the Central Nervous System as a Solution for Time Domain Optical Coherence Tomography Noninvasive Investigation Method. Mat.Plast., 49, no. 3, 2010, p. 201.

11. SUTA, L-M., MATUSZ, P., LEDETI, A., IVAN, C., MURARIU, M., SORA, M.C., LEDETI, I. Embedding of Biliary Calculi in Plastic Materials A viable solution for increasing their mechanical resistance during sampling. Mat.Plast., 53, no. 1, 2015, p. 19.

12. HALLOCK, G.G., Flaps and Reconstructive Surgery, edition 1, Saunders Elsevier, Wei F.C., Mardini S., 2009, pp. 17-28.

13. MATHES, S.J., NAHAI, F. Classification of the vascular anatomy of muscles: experimental and clinical correlation. Plast Reconstr Surg., 67, no. 2, 1981 pp. 177-87.

14. GHETU, N., MOJALLAL, A-A., GHETU, D.E., ILIESCU, V., ILIE, V.I., ILIE, V.G., IONAC, M., MIHALACHE, G., PIEPTU, D. Endoscopic-assisted harvest of pedicled and free latissimus dorsi muscle in pigs. Timisoara Medical J ournal, 60, no. 2-3, 2010, p. 145.

15. NISTOR, A., JIGA, L., GEORGESCU, D., MICLAUS, G., BARAC, S., HOINOIU, B., DUMBULEU, C., IONAC, M. The pig as an ideal training model for perforator flap dissection in living tissue. Plast Reconstr Surg., 133, no. 3 Suppl, 2014, p. 49.

16. HAENSSGEN, K., MAKANYA, A.N., DJ ONOV, V. Casting Materials and their Application in Research and Teaching. Microsc Microanal., 20, no. 3, 2014; pp. 493-513.

17. AULTMAN, A., BLYTHE, A.J ., SOWDER, H., TROTTER, R., RAOOF, $A$. Enhancing the value of organ silicone casts in human gross anatomy education. J Int Soc Plastination, 18, 2003, pp. 9-13.

18. BARONE, R. Anatomie comparée des mammifères domestiques. Tome 2. Arthrologie et myologie. Vigot, Paris, 2010, p.521.

19. SORA, M.C., BRUGGER, P.C., STROBL, B. Shrinkage during E12 plastination. J Int Soc Plastination. 17, 2002; pp. 23-27

\section{Manuscript received: 15.02 .2017}

